\title{
Application of Satellite Monitoring Data for Winter Cereals Growing in the Lviv Region
}

\begin{abstract}
The authors applied satellite monitoring data of agricultural lands of the geographic information system of International Production Assessment Division of the United States Department of Agriculture on the example of winter cereal cultivation. The authors did so according to the indices of vegetation index NDVI, information on atmospheric precipitation, soil moisture, and air temperature compared to Earth observations to estimate the condition of their sowing area. According to the research results, one can use remote sensing data of the IPAD USDA geographic information system to monitor agricultural land, yield capacity prediction and the estimation of gross agricultural products.
\end{abstract}

Keywords: geoinformation system, remote sensing, stages of crop development, vegetation index

Received: 15 April 2020; accepted: 25 July 2020

(C) 2020 Authors. This is an open access publication, which can be used, distributed and reproduced in any medium according to the Creative Commons CC-BY 4.0 License.

1 Lviv National Agrarian University, Department of Land Cadastre, Lviv, Ukraine, email: zemdek@ ukr.net

ORCID ID: https://orcid.org/0000-0002-7599-8261

2 Lviv Polytechnic National University, Department of Cadastre Territories, Lviv, Ukraine, email: nazstupen@gmail.com

ORCID ID: https://orcid.org/0000-0003-1238-4016

3 Lviv National Agrarian University, Department of Geodesy and Geoinformatics, Lviv, Ukraine, email: zoryana.rizhock@gmail.com ORCID ID: https://orcid.org/0000-0002-7599-8261

4 Lviv National Agrarian University, Department of Land Management, Lviv, Ukraine, email: oksanashufryn@ukr.net

ORCID ID: https://orcid.org/0000-0001-6702-0987 


\section{Introduction}

To begin with, there is an urgent need to use geoinformation monitoring data to manage agricultural land use [1]. A vivid example of an existing satellite monitoring system for agricultural production globally is the geoinformation system International Production Assessment Division (IPAD) of the United States Department of Agriculture (USDA) [2]. The main purpose of IPAD is to provide reliable, objective and accurate data on global agricultural production. At the same time, they use remote sensing data of the Earth of high resolution for the estimation of the crop area and expectation of crop yield capacity not only in the USA but also in other countries of the world [3].

In Ukraine, there are also national agricultural monitoring systems using remote sensing data based on the State Space Agency of Ukraine [4] and the National Space Facilities Control and Test Center [5]. Geoinformation portals function on their satellite information.

The aim is to analyze the current state of use of satellite monitoring data use on agricultural lands with the help of the geoinformation system International Production Assessment Division [2]. The potential for its application is presented on the example of the Lviv region based on data of vegetation index NDVI, precipitation, soil moisture and air temperature for the needs of land users.

\section{Materials and Methods}

The authors used the International Production Assessment Division (IPAD) geographic information system of the Foreign Agricultural Service of the United States Department of Agriculture (FAS USDA) to collect market information and predict world production indicators of grain, oil, and cotton products. The users of the server of this system can search and view all available metadata concerning the geographical location of the territory using the tool for inventory data of the geographic information system by such categories such as agricultural regions, lakes and reservoirs, nature of the substructure (Land Cover), precipitation, snow cover, soil moisture, and air temperature. The resources of this system contain agrometeorological information and values of vegetation indices (NDVI) in the form of maps and graphs for diverse countries and Ukraine using a combination of data from Landsat and NOAA-AVHRR satellites to monitor the crop state. The satellites differ in their resolutions of received images of $30 \mathrm{~m}$ and $4 \mathrm{~m} /$ pixel, respectively [6].

The NDVI is one of the most commonly used vegetation indexes. It is calculated based on near-infrared and red light reflectance assessments as:

$$
\text { NDVI }=(\text { nir }- \text { red }) /(\text { nir }+ \text { red }),
$$

where nir and red are the amounts of light reflected by the growing vegetation and registered by the satellite sensor [7]. The NDVI have been widely used to examine the relation between Spectral variability and the changes in vegetation growth rate [8]. 
As an instrument, Land Viewer from Earth Observing System designed for use in remote satellite detection, NDVI has become an inherent part of precision agriculture due to the insights it provides. NDVI offers valuable information on crop yields, vegetation content, the amount of wilting plants, crop classification, and even plant health [9].

\section{Results and Discussion}

The IPAD USDA geoinformation system provides tools for monitoring the world production, stock and consumption of agricultural products and predicts world production indicators to estimate the conditions which influence on food security in the world [10]. The users of this system have access to agrometeorological information, analytical materials on the state of agricultural production and the value of normalized difference vegetation indices (NDVI) in the form of maps and graphs, for countries of the world and Ukraine, which is updated every ten days.

One way to monitor the vegetation state is to determine the vegetation index NDVI - an indicator of the amount of photosynthetic active biomass used for the quantitative evaluation of vegetative cover [11]. According to satellite images, NDVI maps effectively solve the problem of complex analysis of the territory of Ukraine and its individual regions (Fig. 1). Increasing the number of pixels in green indicates an increase in the NDVI values, due to the increase in biomass and vegetation development.

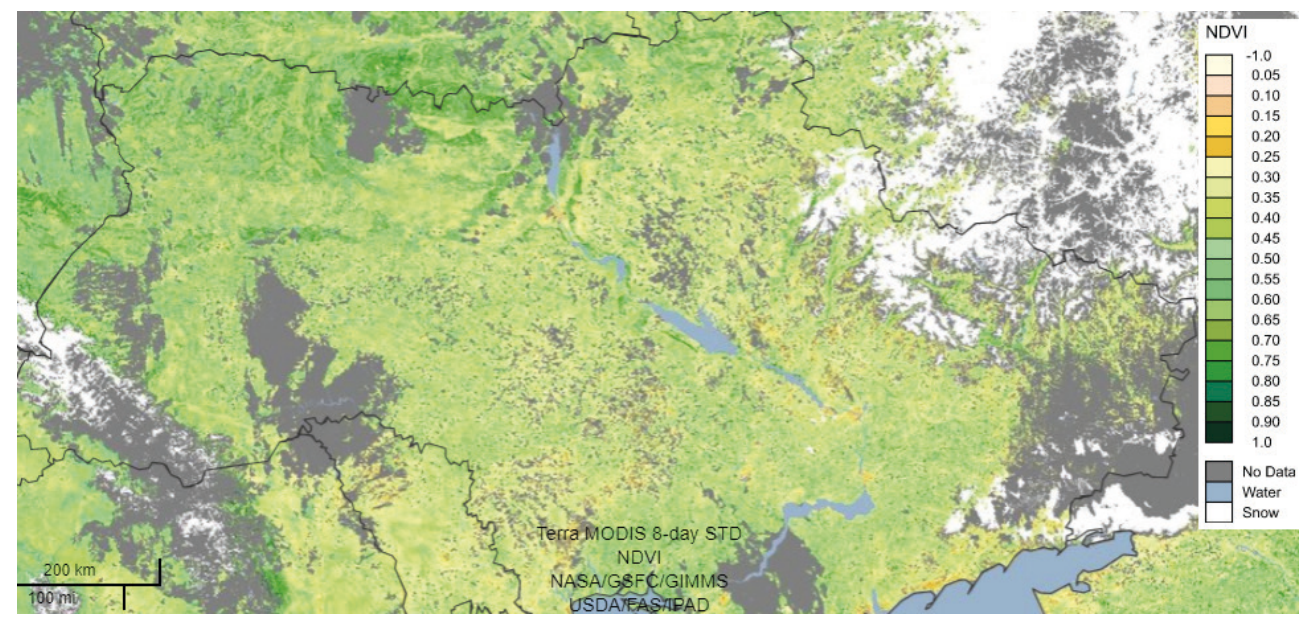

Fig. 1. Raster of NDVI for Ukraine as of February 21-29, 2020 according to IPAD USDA satellite monitoring data

Source: on the basis of data [2]

NDVI helps to differentiate vegetation and determine its general condition using a map visualization tool, which allows the detection of abnormal changes 
in the process of growth. One can achieve it not only according to the satellite monitoring IPAD USDA. For instance, in accordance with the satellite Sentinel data, the geographic information platform Earth Observing System [9] also displays NDVI results, which allows their values to be compared, in contrast to the geographic information system IPAD USDA, at the local level of land use (Fig. 2).

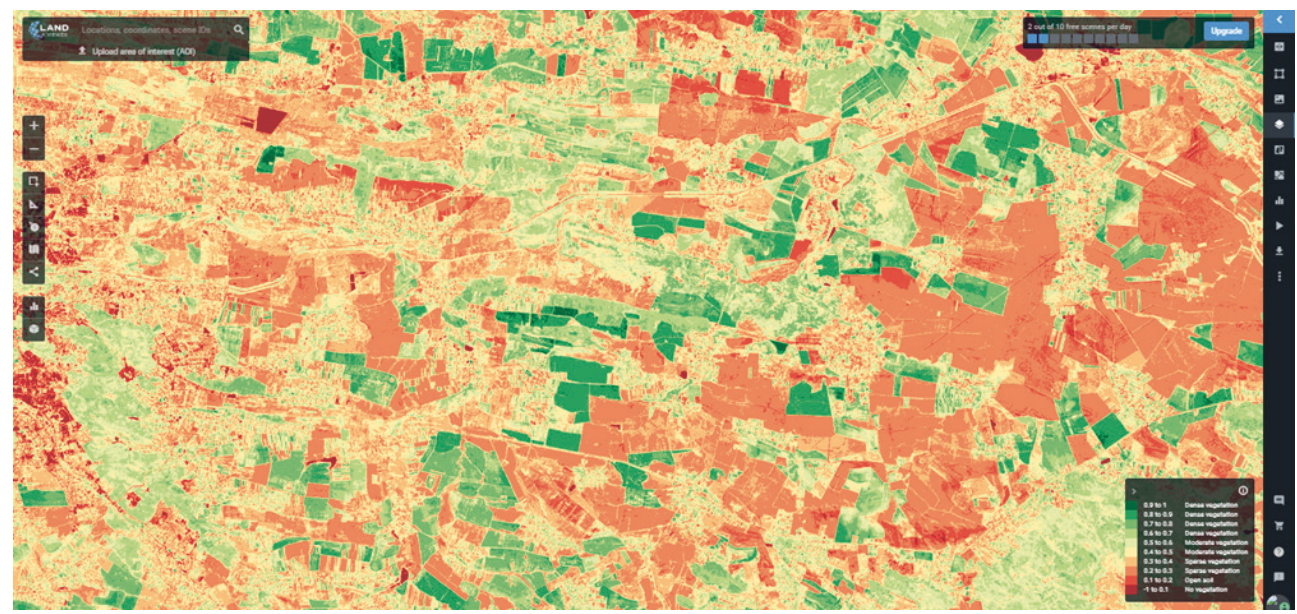

Fig. 2. The raster of NDVI for Lviv region as of February 21-29, 2020 according to the satellite monitoring Earth Observing System data

Source: on the basis of data [9]

The dynamics of the seasonal change of the NDVI makes it possible to carry out a visual and numerical study of the degree of development of crops in different phases of crop vegetation (Fig. 3). The corresponding index will be 0.72 as of June 20, 2020, considering the expected value of the normal curve for the NDVI vegetation index based on data of the years of 2018-2020 in the Lviv region. It indicates the development of dense vegetation in the future.

Information on the analysis on vegetation development using NDVI is extremely useful for government and business entities that make preliminary crop assessment, as it enables managers to make the right management decisions about purchasing or selling agricultural products. Therefore, one should take into account a wider period for 5 years in Ukraine for agricultural land use management, which is presented in Figure 4. One can conclude that the maximum value of NDVI of 0.74 was observed in the middle of June in 2016 and 2017.

The authors have presented Earth observations of the major stages of winter crop development from September 10, 2018 to August 31, 2019 in the Lviv region, and comparisons with IPAD USDA satellite monitoring data in Table 1 from Figure 3, which shows the value of NDVI. 


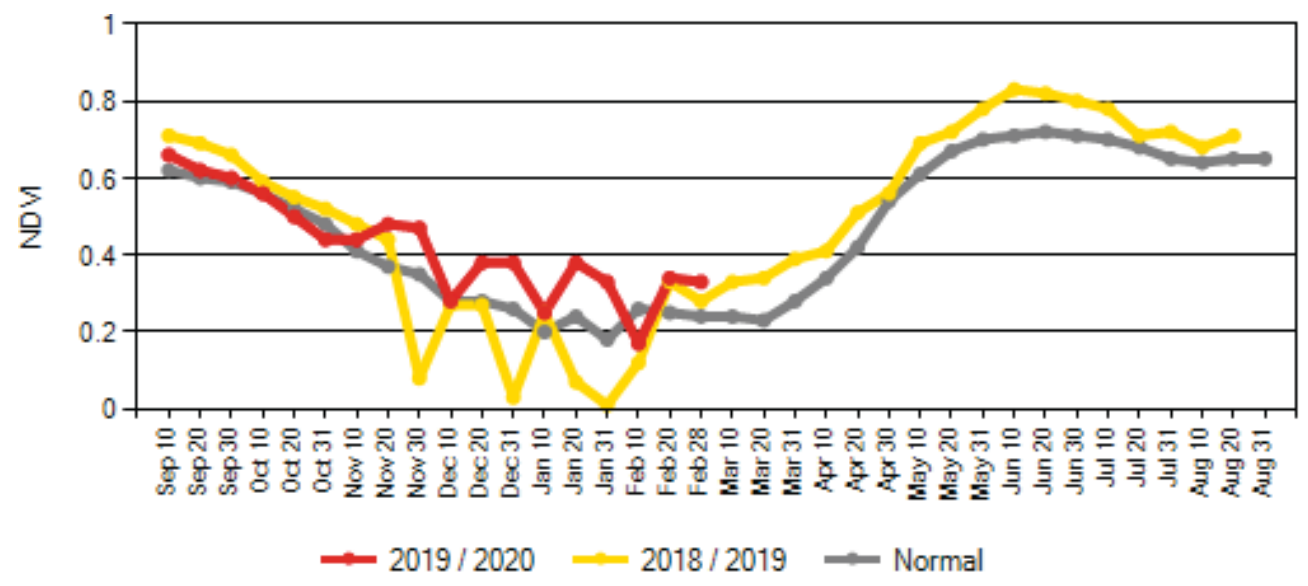

Fig. 3. NDVI curve for winter crops growing in Lviv region during 2018-2020 according to IPAD USDA satellite monitoring

Source: on the basis of data [3]

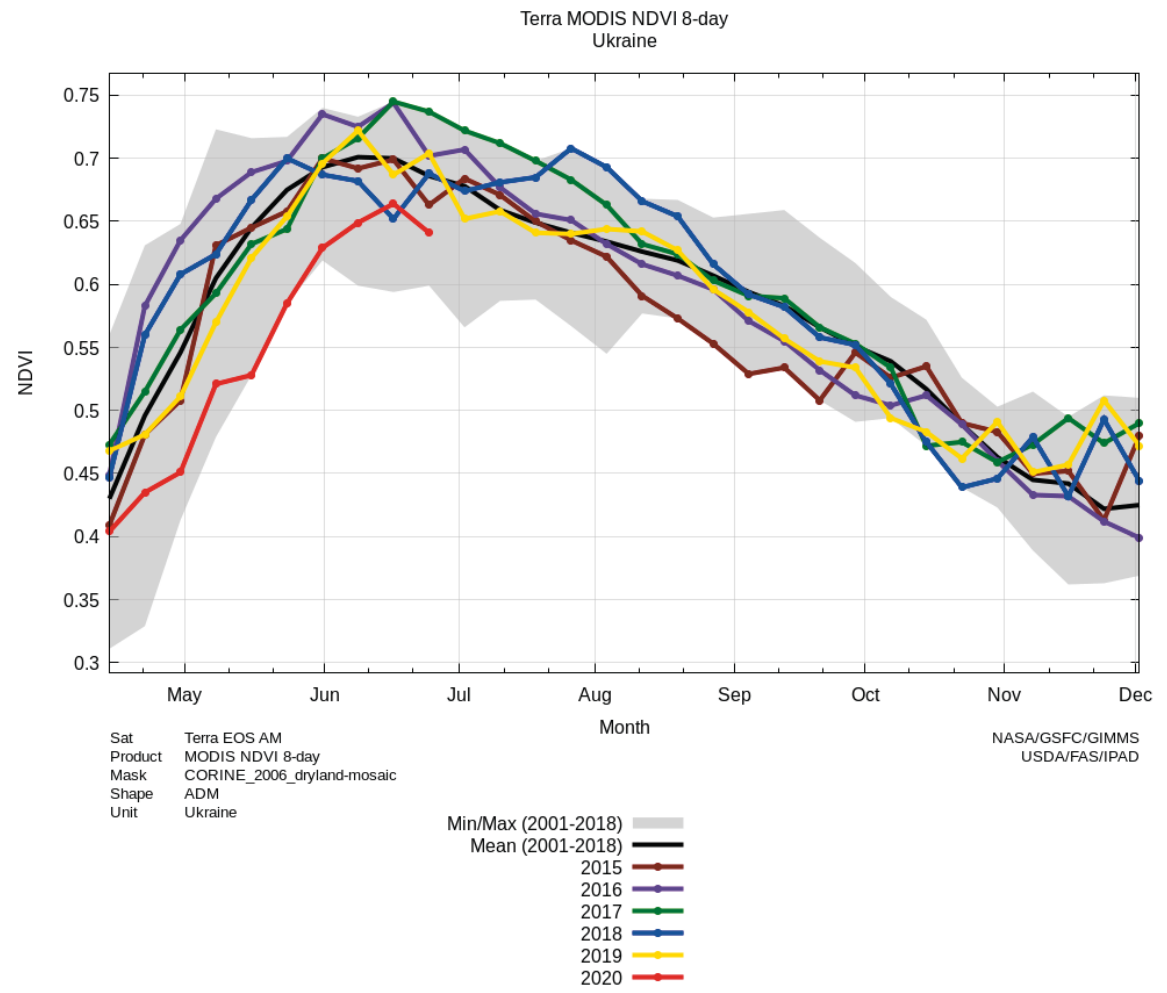

Fig. 4. The curve of NDVI in the cultivation of winter crops in Ukraine during 2015-2020 according to the satellite monitoring IPAD USDA

Source: on the basis of data [2] 
Table 1. Earth observations of winter crops development in the Lviv region for 2018-2019

\begin{tabular}{||l|l|c||}
\hline \multicolumn{1}{|c|}{ Date } & \multicolumn{1}{c|}{ Stage of development } & NDVI values \\
\hline \hline $10.09 .18-20.10 .18$ & germination & $0.71-0.55$ \\
\hline $20.10 .18-30.11 .18$ & seedling & $0.55-0.08$ \\
\hline $30.11 .18-10.12 .18$ & tillering, end of autumn vegetation & $0.08-0.27$ \\
\hline $10.04 .19-20.04 .19$ & tillering, vegetation restoration & $0.27-0.51$ \\
\hline $20.04 .19-30.04 .19$ & tillering & $0.51-0.56$ \\
\hline $30.04 .19-10.05 .19$ & stem elongation & $0.56-0.69$ \\
\hline $10.05 .19-10.06 .19$ & heading, flowering & $0.69-0.83$ \\
\hline $10.06 .19-30.06 .19$ & milky ripe & $0.83-0.80$ \\
\hline $30.06 .19-10.07 .19$ & wax ripe & $0.80-0.78$ \\
\hline $10.07 .19-20.07 .19$ & fully ripe & $0.78-0.71$ \\
\hline $20.07 .19-20.08 .19$ & harvesting & $0.71-0.68$ \\
\hline
\end{tabular}

Source: on the basis of data [2]

The authors have observed that in September and October there were good conditions for sowing and the initial development of winter cereals. The winter wheat sowing density in 2018 ranged from 470 to 655 plants per $1 \mathrm{~m}^{2}$, and the stems respectively 900-1800 pieces. In the tillering stage, the plant formed an average of 1.5-4.3 stems. The results of the vegetation index during the spring of 2019 up to 0.56 made it possible to conclude that winter crops grew well in the tillering stage since the height of the plants was from 15 to $20 \mathrm{~cm}$, which showed the good condition of the crop sowing. Between April 30 and May 10, 2019, winter wheat was in the stem elongation. According to field studies, the height of plants averaged $90 \mathrm{~cm}$ during the period of the heading stage, and the number of productive stems of winter wheat was 400-500 pieces per $1 \mathrm{~m}^{2}$.

The milky ripe stage took place in 2019 from June 10 to June 30. Considering crop monitoring data of the geographic information system Monitoring Agriculture with Remote Sensing (MARS) (Fig. 5), which shows the information on the phases of winter crop development in the EU [12]. The whole ripening of the grain from Earth observations occurred between July 10 and July 20 of this year. At that time, the value of NDVI was in the range of $0.71-0.78$ and indicated that the whole ripening of the plants occurred in June. The height of the plants in the fields was $97-110 \mathrm{~cm}$, and the yield capacity was on average for winter cereals in the Lviv region $-4800 \mathrm{~kg} / \mathrm{ha}$ [9].

The duration of the "seedling-germination" development stage of growing winter cereals is dependent on the temperature and moisture content of the soil. Scientific agrometeorological information helps to decide quickly which actions will be lucrative economically advantageous considering expected weather conditions or already known climatic parameters [13]. The implementation of scientific methods for the use of meteorological information makes it possible to reduce losses in the agricultural economy, due to weather conditions [14]. The precipitation curve for the Lviv region during 2018-2020 according to IPAD USDA satellite monitoring (Fig. 6) allows predicting their average annual value of $23.91 \mathrm{~mm}$ as of July 30 for 
the preparation and implementation of organizational, agro-technical and project events to maximize yield capacity due to current 2020 conditions.

\section{CROP DEVELOPMENT STAGE WINTER WHEAT}

from : 21 July 2019

to : 31 July 2019

Deviation:

Year of interest - LTA

Unit: -

very advanced stage advanced stage slightly advanced stage same stage slightly delayed stage delayed stage very delayed stage.

Fig. 5. The map of phases of winter wheat development for EU countries during July 21-31, 2019 according to satellite monitoring MARS

Source: on the basis of data [12]

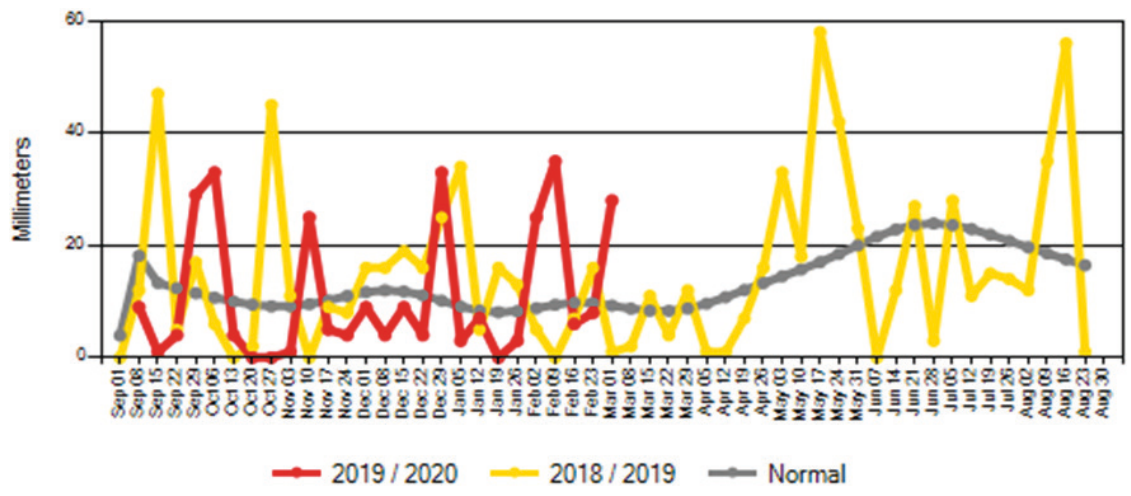

Fig. 6. Precipitation curve for the Lviv region during 2018-2020, according to Satellite IPAD USDA [mm]

Source: on the basis of data [2] 
The optimal amount of atmospheric precipitation during the seedling of winter crops should be 10-20 mm [14]. From Figure 7 according to satellite monitoring data from the IPAD USDA [2], the authors have observed the corresponding amount of precipitation 7 times, including as of September 30, 2018, at the rate of $17 \mathrm{~mm}$. This fact indicates unfavorable conditions for sowing and the initial vegetation of winter crops. At the beginning of April 2019 in the Lviv region, the arable soil was poorly moistened. As of May 3 of this year, the soil moisture of the arable soil (450-550 mm) corresponded to sufficient rainfall of $33 \mathrm{~mm}$ [2]. Their high numbers in the summer provided an intensive development of winter cereals up to the harvesting stage.

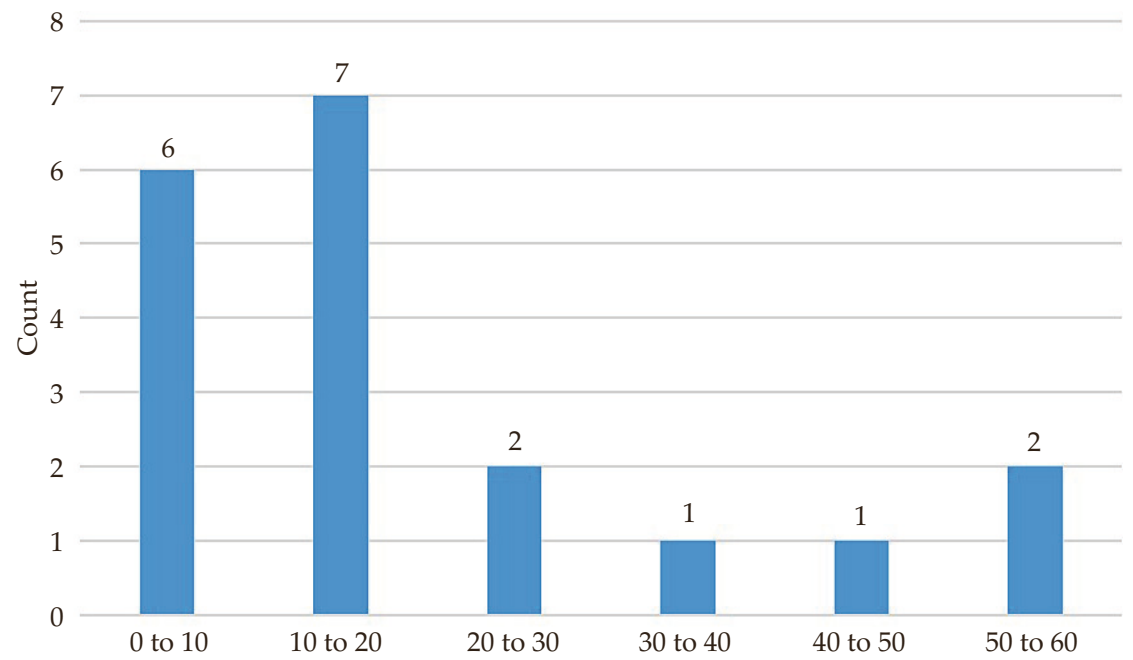

Fig. 7. Precipitation histogram in the Lviv region during the years of 2018-2019, due to IPAD USDA satellite monitoring data [mm]

Source: on the basis of data [2]

Both lack and excess of moisture explains the significant fluctuations in yield capacity $[13,15]$. In arid areas and those with unstable soil moisture, the availability of crops with moisture determines the growing conditions and crop yielding capacity [13]. One can observe the maximum soil moisture (Total Water Content - TWC) for the Lviv region for 2019 on June 2, which is $23.32 \mathrm{~mm}, 2020-23.28 \mathrm{~mm}$ for the standard $1 \mathrm{~m}$ as of February 9 (Fig. 8). One can note the same soil moisture on January 19 and February 9, 2019 and 2020, in the amount of $85.92 \%$ and $88.09 \%$ of field capacity respectively, which indicates sufficient supply of plants with moisture.

The authors investigated that the average soil moisture (TWC) content is $18.82 \mathrm{~mm}$ and indicates its good security in accordance with 50 observations of IPAD USDA satellite monitoring for the Lviv region during 2018-2019 (Fig. 8). From the data in Figure 9, one can observe a diagram of soil moisture (TWC) distribution, where its maximum value is $23.32 \mathrm{~mm}$ and the minimum one is $12.75 \mathrm{~mm}$. 
The authors made the diagram box from quartile to quartile, the upper limit of which is set at $20.90 \mathrm{~mm}$, the lower one is at $16.23 \mathrm{~mm}$, and the risk is a median of $18.46 \mathrm{~mm}$ of soil moisture (TWC).

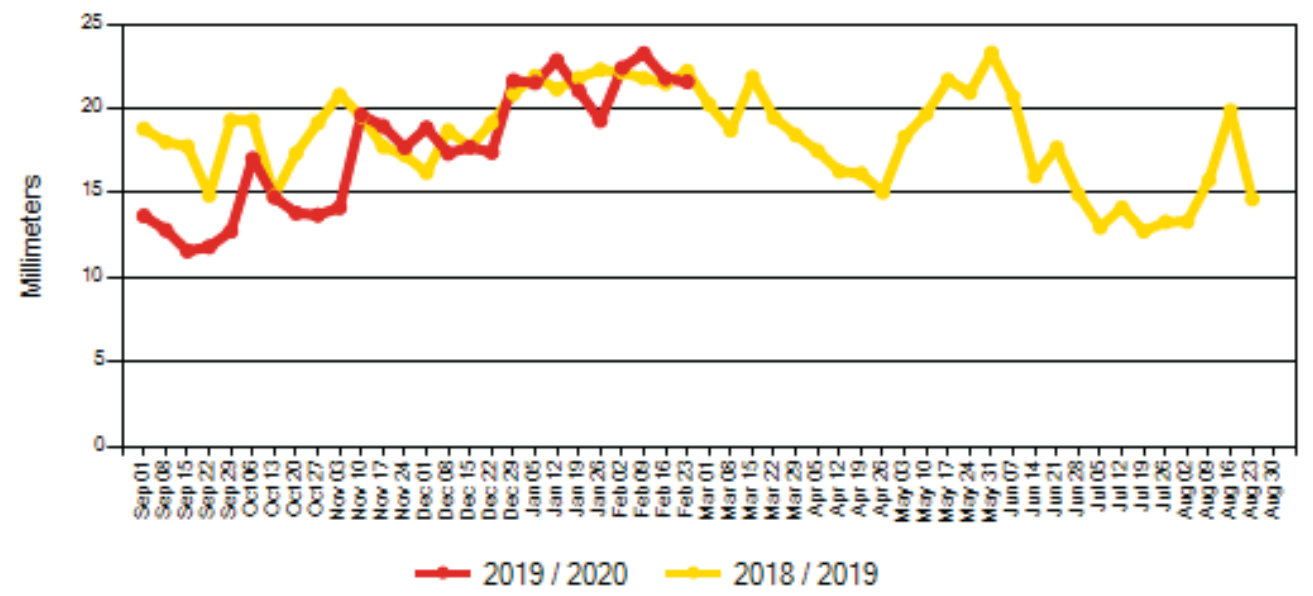

Fig. 8. Soil moisture curve for the Lviv region during the years of 2018-2020 due to IPAD USDA satellite monitoring data [mm]

Source: on the basis of data [2]

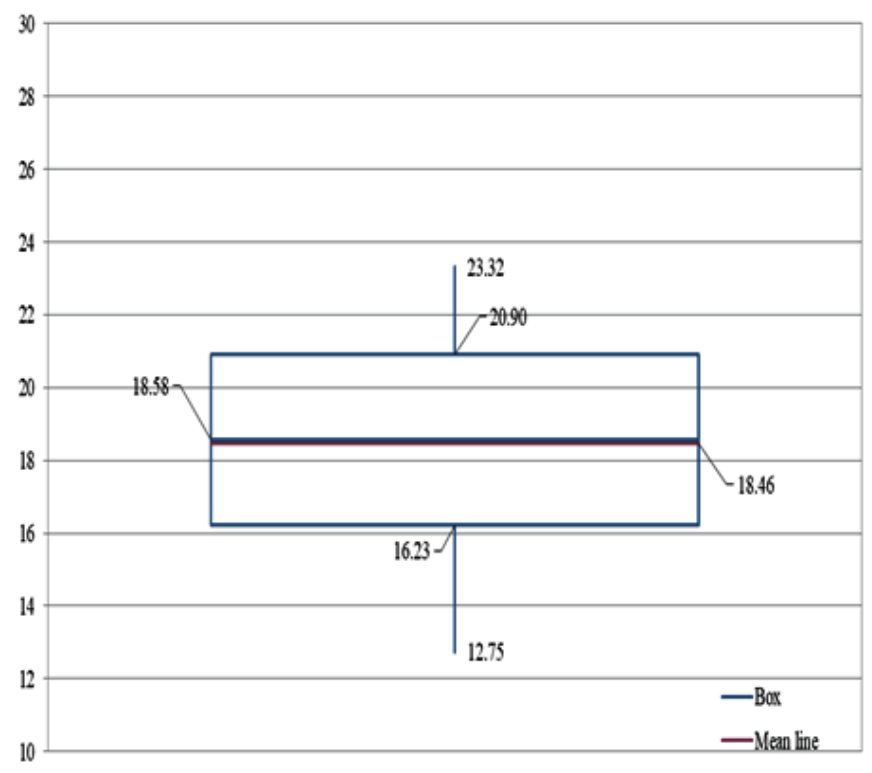

Fig. 9. Soil moisture (TWC) distribution diagram for the Lviv region during 2018-2019 according to IPAD USDA satellite monitoring data [mm]

Source: on the basis of data [2] 
In Figure 10, a combined curve with a trend line for data on precipitation and soil moisture (TWC) in winter crop cultivation in the Lviv region during 2018-2019 is presented. Concerning the trend line, one can draw the conclusion that a close relationship is established between these data at 0.97 for the correlation coefficient. Analyzing this figure, one can observe that in the period from April 10 to May 10, 2019 , the results of the study are the same. Considering the period from December 31, 2018 to February 28, 2019 and from May 20 to June 10, 2019, the moisturizing of the arable layer for the $1-\mathrm{m}$ of the soil corresponds to sufficient and optimal values of more than $20 \mathrm{~mm}$ of productive moisture (TWC).

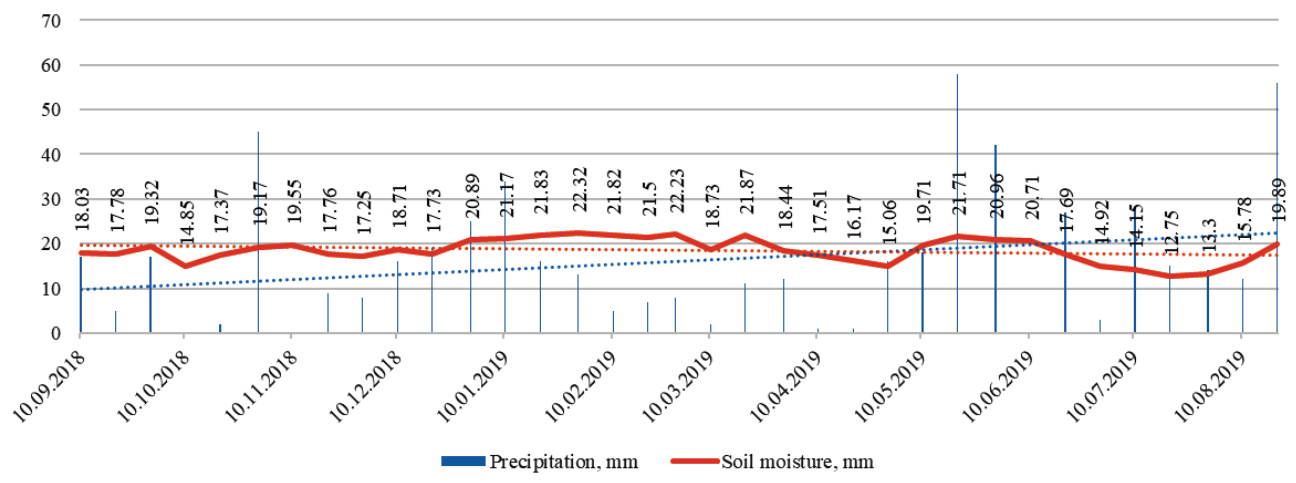

Fig. 10. The combined curve of precipitation, soil moisture (TWC) in winter crop cultivation in the Lviv region during 2018-2019 according to the satellite monitoring IPAD USDA

Source: on the basis of data [2]

The moderate temperature regime in autumn created favorable conditions for the provision of seedling, tillering and growing of the vegetative mass of winter cereals. As Figure 11 shows, there is a graph of air temperature in Lviv region during 2018-2020, due to IPAD USDA satellite monitoring data [2]. Having studied data, the end of February was cold. The final destruction of the snow cover and thawing occurred only in the middle of March 2019. Active spring processes in the Lviv region began in the middle of April with rising air temperatures. The minimum temperature in January was $-7^{\circ} \mathrm{C}$, and the maximum was $23^{\circ} \mathrm{C}$ in July 2019.

\section{Conclusions}

In general, the findings of the article suggest that the geoinformation system IPAD USDA satellite monitoring data provide an open source of information for users from different countries who can use it to evaluate crop state at the national level based on NDVI, precipitation, soil moisture, air temperature and others. The analysis results of the vegetation index (NDVI) allow contrasting them with 
ground-based observations of winter crops in the Lviv region for 2018-2019, predict their yields and determining that the full plant ripeness from June 10, 2019 to June 30, 2019 according to the values of the corresponding indicator of $0.71-0.78$. Analysis of the amount of precipitation for the object of study allows predicting their average value of $23.91 \mathrm{~mm}$ on July 30, 2019. One observes the maximum soil moisture (TWC) for the standard $1 \mathrm{~m}$ for the Lviv region for the year of 2019 on June 2, which is $23.32 \mathrm{~cm}$. The use of air temperature indicators allowed the determination of favorable conditions for increasing the vegetation mass of winter grain crops.

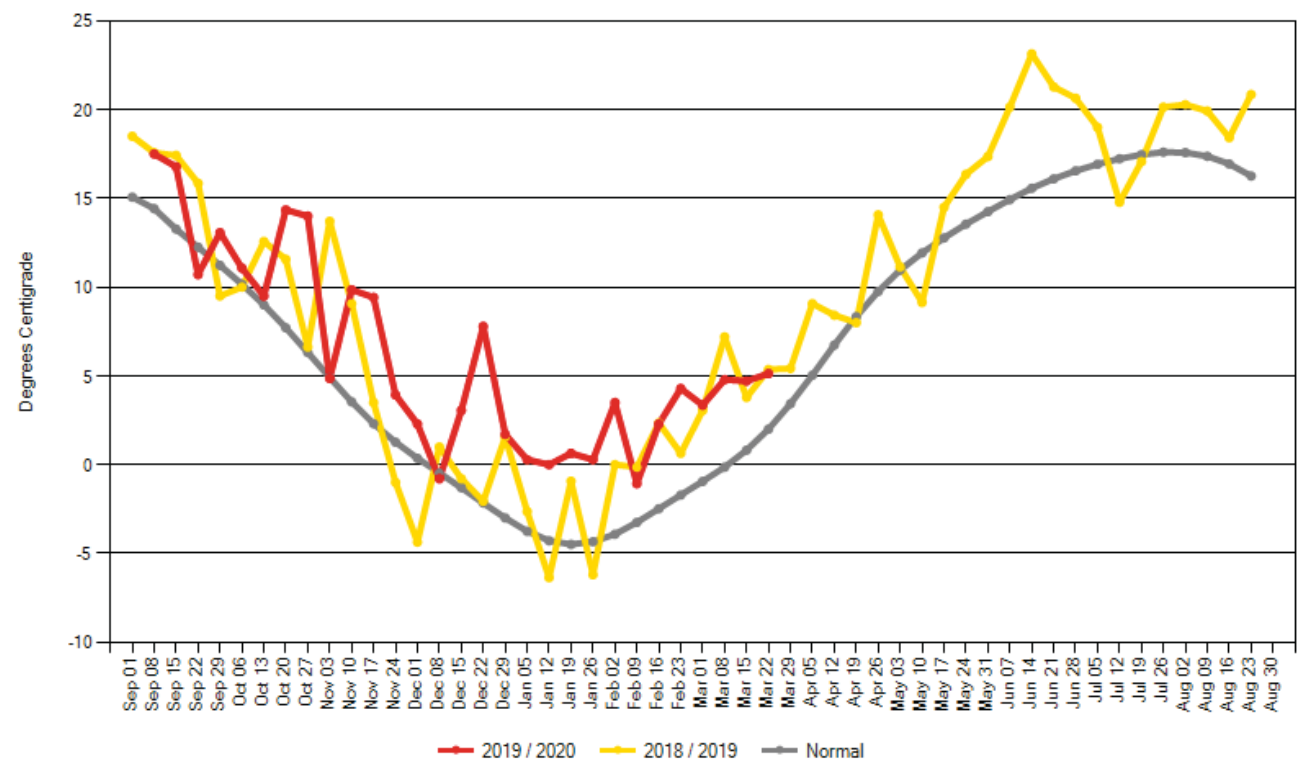

Fig. 11. Air temperature curve in the Lviv region during 2018-2020 according to IPAD USDA satellite monitoring data $\left[{ }^{\circ} \mathrm{C}\right]$

Source: on the basis of data [2]

\section{References}

[1] Stupen N., Stupen M., Stupen O.: Electronic Agricultural Maps Formation on the basis of GIS and Earth Remote Sensing. Management, Economic Engineering in Agriculture and Rural Development, vol. 18 (4), 2018, pp. 347-353.

[2] International Production Assessment Division, https://ipad.fas.usda.gov/ cropexplorer/imageview.aspx?regionid=umb [access: 24.03.2020].

[3] Doraiswamy P.C., Hatfield J.L., Jackson T.J.: Crop Condition and Yield Simulations using Landsat and MODIS. Remote Sensing of Environment, vol. 92 (4), 2004, pp. 548-559. 
[4] State Space Agency of Ukraine, http://portal.dzz.gov.ua/geoportal/ [access: 22.03.2020].

[5] National Space Facilities Control and Test Center, [on-line:] http://spacecenter.gov.ua/ [access: 22.03.2020].

[6] Kolodiy P., Pidlypna M.: The Improvement of the Agricultural Yields Forecasting Model Using the Software Product "Land Viewer". Geomatics and Environmental Engineering, vol. 14, no. 1, 2020, pp. 59-67.

[7] Borowik T., Pettorelli N., Sönnichsen L., Jędrzejewska B.: Normalized difference vegetation index (NDVI) as a predictor of forage availability for ungulates in forest and field habitats. European Journal of Wildlife Research, vol. 59 (5), 2013, pp. 675-682.

[8] Meera Gandhi G., Parthiban S., Thummalu N., Christy A.: NDVI: vegetation change detection using remote sensing and GIS - a case study of Vellore District. Procedia Computer Science, vol. 57, 2015, pp. 1999-1210.

[9] Earth Observing System, https://eos.com/lv/ [access: 2.07.2020].

[10] Serdyuchenko N.M.: Analiz System Ahromonitorynhu Transnatsional'noho Rivnya. Tekhniko-Tekhnolohichni Aspekty Rozvytku ta Vyprobuvannya Novoyi Tekhniky i Tekhnolohiy dlya Sil's'koho Hospodarstva Ukrayiny [Сердюченко Н.М.: Аналіз Систем Агромоніторингу Транснаціонального Рівня. Техніко-Технологічні Аспекти Розвитку та Випробування Нової Техніки і Технологій для Сільського Господарства України], по. 22 (36), 2018, pp. 159-165.

[11] Zatserkovnyy V.I., Kryvoberets' S.V., Serhiyenko V.V.: Vykorystannya HIS ta DZZ dlya monitorynhu sil's'kohospodars'kykh zemel'. Chernihivs'kyy naukovyy chasopys Chernihivs'koho derzhavnoho instytutu ekonomiky i upravlinnya. Tekhnika i pryroda [Зацерковний В.I., Кривоберець С.В., Сергієнко В.В.: Використання ГІС та ДЗЗ для моніторингу сільськогосподарських земель. Чернігівський науковий часопис Чернігівського державного інституту економіки і управління. Техніка і природа], по. 2, 2011, pp. 40-48.

[12] Monitoring Agriculture with Remote Sensing, http://www.marsop.info/en/ web/mars-explorer/home [access: 2.07.2020].

[13] Stupen M., Stupen R., Ryzhok Z., Stupen O.: Methodological foundations of the organization and protection of lands in the context of the balanced nature use. Management, Economic Engineering in Agriculture and Rural Development, vol. 19 (1), 2019, pp. 565-571.

[14] Bozhko L., Barsukova O.: Ahrometeorolohichni prohnozy. Odes'kyy derzhavnyy ekolohichnyy universytet, Odesa 2011 [Божко П., Барсукова О.: Агрометеорологічні прогнози. Одеський державний екологічний університет, Одеса 2011].

[15] Stupen N., Bohira M., Stupen O., Ryzhok Z.: Prospects of the Application of European Practice on Efficient Agricultural Lands Use in Ukraine. Management, Economic Engineering in Agriculture and Rural Development, vol. 19 (3), 2019, pp. 563-569. 